Lee, K., Ardeshiri, M., \& Cummins, J. (2016). A computer-assisted multiliteracies programme as an alternative approach to EFL instruction. Technology, Pedagogy and Education. doi: 10.1080/1475939X.2015.1118403

\title{
A Computer-assisted Multiliteracies Program as an Alternative Approach to EFL Instruction
}

The aim of this paper is to introduce a computer-assisted multiliteracies program (CaMP) as an alternative approach to English as a Foreign Language (EFL) instruction in order to overcome the educational limitations that are inherent in most EFL settings. In a number of monolingual societies with a dominant language other than English, students have had unequal access to authentic English communication opportunities and consequently have a limited understanding of English as American English or native speakers’ English. Although communication technologies have been regarded as a promising solution, the limitations within EFL education have not been fully addressed. In this paper, multiliteracies pedagogy is offered as a promising solution enabling students to improve English and both cultural and media literacies. This paper provides an in-depth description of effective ways to integrate the multiliteracies pedagogy in EFL instruction and its potential effects on EFL students’ learning experiences.

\section{Background}

In this age of globalization, the importance of English as a global language used for international communication has been rapidly growing not only in English speaking countries but also in non-English speaking countries including monolingual societies such as Korea and Japan (e.g., Kennedy, 2006;

Kramsch, 2014; Nunan, 2003). In South Korea (hereafter referred as “Korea”) where English was long taught as a “foreign” language (EFL), for example, there has been a proliferation of social and political discourses of globalization and enormous national efforts to designate English as an official language throughout the 1990s and well into the new millennium (Song, 2011; Yoo, 2005). Along with this political movement, there have been multiple educational projects that have emphasized the use of speaking skills in the English curriculum to improve students' global communication competence (Butler, 2005; Kim, 2006; Shim \& Baik, 2000). A great number of Korean students, however, often have neither motivation to learn English nor opportunities to communicate in English (Kim, 2013). In particular, the 

approach to EFL instruction. Technology, Pedagogy and Education. doi: 10.1080/1475939X.2015.1118403

low relevance of English language to students’ daily communication practices has been repeatedly reported as the reason for English teachers failing to engage their students in communicative learning practices (Bax, 2003; Jeon, 2009; Li, 1998). In such EFL contexts, there have been growing concerns related to the gap between political insistence on increasing national competitiveness through improving individuals’ English competence and the current public English education system, which is not effectively fulfilling its mission (Song, 2011).

The growing attention to EFL education and its contextual limitations have brought about various efforts to address the challenge in EFL learning settings. Emerging technologies are one of the most available alternative tools for EFL learning and teaching, and computer-assisted language learning software and programs, focused on particular language skills (e.g., listening, grammar, pronunciation) have been implemented and researched (Cummins, Brown, \& Sayers, 2007; Golonka et al., 2012; Stockwell, 2007; Wigham, 2013). Through the broad proliferation of Internet use, EFL students have increasing access to diverse authentic English media products online (e.g., YouTube videos, BBC news, open educational resources) that can be used for both language learning and entertainment. In classroom settings, teachers are also using such resources to offer students more entertaining audience-based learning opportunities to expose them to real-life English communication experiences in diverse situations to increase students' learning motivation (Bonk, 2009). More interactive and participatory applications such as social networking sites (e.g., Facebook, Myspace) and computer-mediated communication tools (e.g. email, weblogs, Videoconferening) enable EFL students to interact with foreign people in English (Hsu, Wang, \& Comac, 2008; Mahdi \& El-Naime, 2012; O’Dowd, 2007; Schenker, 2012; Yang, 2011; Yang \& Chen, 2014). Using these strategies, computer-assisted English teaching was expected to overcome the inherent limitations in EFL learning contexts including a lack of opportunities to use English in real-life communication.

\section{Problem}



approach to EFL instruction. Technology, Pedagogy and Education. doi: 10.1080/1475939X.2015.1118403

The continuing pedagogical efforts to improve the quality of English education using technologies have alleviated neither the thirst for authentic English learning opportunities nor subsequent social issues related to the excessive emphasis on English in Korea. This section will briefly discuss two fundamental problems arising from current English language learning practices in Korea and broadly in many EFL countries.

Despite its contextual limitation that English is not a medium of everyday communication in Korea, there has been a high demand for English communicative competence throughout Korean society, which is often described as 'English fever’ in Korea (Kim, 2006; Park, 2009). In this situation, the growing dissatisfaction with public English education system has led to Korean parents' excessive financial investment in their children's private English lessons and it has further caused some peculiar social phenomena. One example is an emerging phenomenon of the 'wild goose family' referring to families sending their children abroad (to the U.S. or other English speaking countries) to experience authentic communicative English learning opportunities (Kim, 2010). Such children travel either alone or with their mothers while fathers remain in Korea working to provide financial support for their children. Although this kind of mobilization for English education has contributed to improving English competence among some Korean students (Lee, 2010), other social issues associated with family separation or identity formation have been caused (Shin, 2010). Also, not all parents can afford this extremely expensive private English education (Park \& Abelman, 2004). Consequently, one's level of English proficiency in Korea tends to be closely linked to one’s social and cultural capital as several studies demonstrate that English has been recruited to reinforce the existing social hierarchy between the privileged classes and the other classes of Korean society (Lee, 2010; Lin, 1999; Song, 2011; Warschauer; 2000).

Researchers have suggested different perspectives, interpretations, and concerns about ideological effects of globalization and global English on local or subgroups' cultures in both English speaking and 

approach to EFL instruction. Technology, Pedagogy and Education. doi: 10.1080/1475939X.2015.1118403

non-speaking contexts (for a few recent examples, Barman \& Miluwi, 2013; Coluzzi, 2012; Feigenbaum, 2011; Jiang, 2011; Qu, 2011). Language and culture are intricately interwoven (Brown, 2006)—language is an integral part of a culture and it also shapes culture (Kramsch, 1998)—thus influencing people's values and their world view (Gramsci, 1971). Due to this inextricable connection between culture and language, the wide acceptance of English as a global language and the growing dependence on English communication practices have raised concerns such as the impact of American cultural imperialism or colonialism (Coluzzi, 2012). Jiang (2011) shows the widespread impact of Western culture among Chinese students (e.g., Christmas, Halloween, KFC, MacDonald's) and with the increasing value placed on English competence, students can be influenced to believe that English and American culture is superior to Chinese and Chinese culture. Guo (2012) also observed a similar cultural understanding among both Chinese students and teachers. Teachers tend tobelieve that teaching English is also teaching American culture that effectively replaces Chinese-based English teaching materials with American cultural products (e.g., The Simpsons) without consideration for their cultural effects on their students. These EFL teaching practices are in line with Moran’s (2001) argument that one should first learn something of the culture of a target language so the cultural knowledge should (and could) be taught in language classrooms. Although this approach has been much questioned in ESL context (e.g., Barman \& Miluwi, 2013), it is still common in EFL classrooms to overemphasize the importance of "knowing about the U.S.” and to promote (or misrepresent) U.S. culture as aunitary global or modern culture (Jameson \& Masao, 1998). In fact, the dominance of U.S. culture has been observed across Korea (Jin, 2007) and a growing number of Korean studentstraveling to the U.S. to learn both English language and American culture can be seen as evidence of the linguistic and culturally imperialistic effects of these educational practices.

To address these educational challenges of EFL learning including the lack of situated learning opportunities and the social inequities emerging from the excessive emphasis on English in Korea, we present in this paper an alternative EFL learning and teaching approach based on a concept of 
Lee, K., Ardeshiri, M., \& Cummins, J. (2016). A computer-assisted multiliteracies programme as an alternative approach to EFL instruction. Technology, Pedagogy and Education. doi: 10.1080/1475939X.2015.1118403

“multiliteracies” and we describe ourcomputer-assisted multiliteracies program (CaMP) as an example.

\section{“Multiliteracies” as an EFL Learning and Teaching Approach}

The New London Group (1996), a group of literacy and language educators, collectively coined the term 'multiliteracies' to expand the traditional language-based approach to literacy, which failed to capture the complexity and multi-faceted nature of emerging communication practices. Globalization and digitalization have facilitated the origin, as well as the rapid acceptance of, multiliteracies in educational contexts (Kalantzis \& Cope, 2008; Mills, 2009). From the pedagogical perspective of multiliteracies, learnersas meaning makers need to acquire multiple sets of skills to negotiate the diverse linguistic and cultural differences in theirglobalized or multicultural communication environment (Jenkins, 2004). Learners are also expected to have an expanded knowledge base to create meanings in diverse forms, using both traditional and digital texts, and exchange meanings through multiple communication channels including digital communication technologies (Cope \& Kalantzis, 2009). On account of its multidimensional nature, researchers have examined diversedimensions of literacy such as linguistic literacy, language literacy, digital literacy, media literacy, cultural literacy, critical literacy, and information literacy (Alexander, 2008; Buckingham, 2003; 2007; Gee, 2012; Koltay, 2011; Nowell, 2014; Sefton-Green, Nixon, \& Erstad, 2009). The multiliteracies discussed in this paper focus on three different literacies: English language literacy, cultural literacy, and media literacy.

English language literacy can be simply defined as the ability to communicate in English (Moats, 2000). Although aholistic understanding of communicative competence (i.e., including all reading, writing, spelling, listening, speaking skills) has been promoted in the current English curriculum, actual classroom practices in Korea tend to concentrate on a limited set of linguistic skills such as reading and spelling (Butler, 2011; Jeon, 2009). This could be due to either a lack of oral communication skills among Korean English teachers who are non-native English speakers (Li, 1998; Kim, 2006) or an exam-oriented Korean education system where written tests are the main measure of students' English competence. 
Lee, K., Ardeshiri, M., \& Cummins, J. (2016). A computer-assisted multiliteracies programme as an alternative approach to EFL instruction. Technology, Pedagogy and Education. doi: 10.1080/1475939X.2015.1118403

However, language literacy is regarded as a basic literacy necessary for one’s development and participation in social communities in which communication using a particular language takes place:

Literacy is the ability to identify, understand, interpret, create, communicate, compute and use printed and written materials associated with varying contexts. Literacy involves a continuum of learning in enabling individuals to achieve their goals, to develop their knowledge and potential, and to participate fully in their community and wider society (UNESCO, 2004, p.14).

In this global society where communication often takes place using English, therefore, the focus of English language teaching and learning needs to be expanded to include the holistic communication function of English rather than being limited to certain linguistic skills (OECD, 2011).

On the other hand, researchers have questioned the conventional approach to English education that emphasizes the Standard English (Kramsch, 2014; Tanghe, 2014). Nevertheless, American English has maintained its privileged status in Korean and some Asian countries as so-called "native speakers' English” (Park, 2009). For example, it is often believed that native speakers could teach English better (Guo, 2012). The Korean government, therefore, has hired a large number of native-speaker teachers to teach English at public schools and has strictly limited its recruitment to 'a citizen of a country where English is the primary language' through its visa system (Consulate General of the Republic of Korea, 2011 cited in Tanghe, 2014). Having acknowledged the intertwined relationship between language and culture (Brown, 2006; Kramsch, 1998), and in a communication environment where linguistic and cultural diversity among communicators is increasing, our perspective on English should also be shifted from a narrow focus on American English to a broader understanding of World Englishes (Kachru, 1985). Inviting World Englishes into English classrooms requires both Korean teachers and students to transform their attitude towards different forms of English including multiple accents as well as functional grammar and cultures that they are not familiar with (Kalantzis \& Cope, 2008). This is where cultural literacy education can be a valuable addition. 
Lee, K., Ardeshiri, M., \& Cummins, J. (2016). A computer-assisted multiliteracies programme as an alternative approach to EFL instruction. Technology, Pedagogy and Education. doi: 10.1080/1475939X.2015.1118403

The concept of cultural literacy was originally suggested by an U.S. educator and academic literary critic, E.D. Hirsch (1988), in his book Cultural literacy: What every American needs to know. Hirsch defines cultural literacy as core factual knowledge a person should learn in order to effectively communicate with other people and argues that public schools must teach the 'right core knowledge' aboutthe U.S. to develop students as a good U.S. citizen. However, Hirsch’s notion of cultural literacy is not able to reflect the growing cultural diversity in the U.S. and worldwide (Aronowitz \& Giroux, 1991). Hirsch's list of cultural facts only represents cultural characteristics of a dominant social group (i.e., white middle-class) as the U.S. cultural canon without consideration of diverse cultural characteristics across social groups in the U.S. This notion of cultural literacy has been strongly criticized and even called cultural illiteracy by some other researchers in second language learning (e.g., Cummins, 2001; Cummins \& Sayers, 1995). Claiming that school is a site for providing students with opportunities to participate in diverse cultural discussions relevant to their own lives and identities (Buckingham, 2003; Giroux, 1999) and not for disseminating a particular form of cultural knowledge, we will use a definition of multicultural literacy that reflects this claim: 'the ability to understand and appreciate the similarities and differences in the customs, values, and beliefs of one's own culture and the cultures of others' (Metiri Group, 2003).

In a similar vein, Byram (1997) suggests an intercultural language teaching model that incorporates multicultural perspective into language teaching context. His model aims:

to give learners intercultural competence as well as linguistic competence; to prepare them for interaction with people of other cultures; to enable them to understand and accept people from other cultures as individuals with other distinctive perspectives, values and behaviors; and to help them to see that such interaction is an enriching experience (Byram, Gribkova, \& Starkey, 2002, p. $10)$.

Byram’s (2012) model can be particularly useful for transforming English teaching practices in Korea and 

approach to EFL instruction. Technology, Pedagogy and Education. doi: 10.1080/1475939X.2015.1118403

other EFL countries where the U.S. (or Western) culture is often perceived superior to other cultures. Rather than limiting our cultural focus to the culture of English-speaking countries, therefore, we should allow our students' own culture to permeate the classroom dialogues as well as facilitate students' critical cultural awareness of diverse cultures in this global world.An increasing number of foreign language educators have adopted the intercultural language teaching model and proposed pedagogical principles that facilitate students' intercultural communicative competence (ICC) acquisition (Liu \& Zhang, 2014; Lussier, 2007; Sercu, 2002; Young \& Sachdev, 2011; Yunlong, 2014). Sercu (2002), for example, asserts that a student-centered autonomous learning approach, rather than traditional teacher-led language-and-teaching instruction, improves students’ ICC. Liu and Zhang (2014) similarly argue that students acquire ICC not through teacher-transmitted knowledge but through their own learning initiatives. Lussier (2007), therefore, suggests that students need to experience diverse cultural interactions and transactions with others in their learning process.

Emerging computer-mediated communication (CMC) technologies have facilitated the realization of these pedagogical principles in EFL classroom settings. Computer-assisted collaborative projects or intercultural projects between different countries have been utilized in EFL classrooms. For example, Yang and Chen (2014) provided Taiwanese students in $7^{\text {th }}$ grade with a series of intercultural communication opportunities in English with students in Dubai, Pakistan and the USA using CMC tools (e.g., online forums, weblogs, Skype, and email). Other examples include Japanese university students communicating with Hungarian, American, Taiwanese, and Turkish students (Bray, 2010), Germen university students with Irish and American students (O’Dowd, 2007) and Germen high school students communicating with American college students (Schenker, 2012). All these studies similarly demonstrate the effectiveness of this pedagogical approach for developing both linguistic and cultural competences among EFL students. However, the instrumental view of online technologies as only a tool for improving learning seems insufficient for improving young students’ media literacy, which is another necessary skill to be an active meaning-maker in this digitalized society (Erstad, 2006). 
Lee, K., Ardeshiri, M., \& Cummins, J. (2016). A computer-assisted multiliteracies programme as an alternative approach to EFL instruction. Technology, Pedagogy and Education. doi: 10.1080/1475939X.2015.1118403

Weaver (2009) argues that it has become possible for ordinary people to access, generate and distribute different forms of political messages using emerging media technologies. Buckingham (2003; 2007) also argues that new digital media technologies—Web 2.0 technologies in particular—have major roles in constructing and distributing a massive amount of political ideas and social representations, and as a result, developing and transforming individual's perspectives. In this social context, students need to acquire the competences to be able to access, analyze and evaluate information in various digital forms and use new media technologies to construct and distribute their own ideas. In this way, media literacy—sometimes called digital or information literacy—refers to the ability to be a critical consumer and active producer of media used to question, challenge and reconstruct political and commercial messages (Bowen, 1996; Koltay, 2011). One way of teaching media literacy is to engage students in collaborative media production, providing hands-on experiences of creating and sharing digital products using various media technologies and resources (Buckingham, 2003). This type of pedagogical method also enables students to experience diverse forms of participatory communication culture within the particular society (Jenkins, 2006). This may allow students to experience 'affiliations', whereby they attain formal or informal memberships in both face-to-face and online communities; 'expressions', where they produce creative forms of digital content; 'collaborative problem solving', where they work together in teams to complete tasks and develop new knowledge; and 'circulations', where they shape the flow of media.

We believe that a comprehensive framework of multiliteracies that consists of English language, cultural, and media literacies would be a promising alternative to the current EFL teaching approach. Although there have been a number of attempts to integrate multiliteracies pedagogy into first language teaching contexts (e.g., Alexander, 2008; Cooper, Lockyer, \& Brown, 2013; Nowell, 2014; Tan \& Guo, 2014), such a pedagogical approach has rarely been implemented into EFL settings with a few exceptions (e.g., Guth \& Helm, 2012). To fill this gap, we designed and implemented a Computer-assisted Multiliteracies Program (CaMP) in an EFL classroom in a Korean public middle school. 
Lee, K., Ardeshiri, M., \& Cummins, J. (2016). A computer-assisted multiliteracies programme as an alternative approach to EFL instruction. Technology, Pedagogy and Education. doi: 10.1080/1475939X.2015.1118403

\section{Research Methods and Data}

The two research questions that are addressed in this paper are: a) how can multiliteracies pedagogy be effectively integrated in EFL instruction? and b) what are EFL students' learning experiences in the EFL instruction informed by the multiliteracies pedagogy? To effectively address these questions, we took a design research approach that aims to solve educational problems, implement theories in pedagogical practice for testing, and develop practical knowledge that can be applied into other educational contexts (Edelson, 2002). The important focus of design research is to derive its findings not from narrow and mechanical measures of learning outcome but from holistic and authentic formative evaluation of learning process (Collins, Joseph, \& Bielaczyc, 2004).

In this qualitative study, a computer-assisted multiliteracies program, called “CaMP” and a CaMP website to run the programwere first developed. The three week-long CaMP was implemented inan English communication course in a Korean public middle school during the summer session. 23 Korean students registered for the program and later agreed to participate in this research project. Informed consent from their parents and the school principal to the use of data in the class website was also obtained. All student participants were in grade 7 to 9. Although the level of English among students was varied, most students were at a beginner-level. In a partner class, 22 individual Iranian students attending different schools in the same neighborhood were recruited and participated. The Korean class was connected to the Iranian partner class through the class website in which different CMC tools were embedded (a detailed description of the website will be provided in the next section).

The most important data source werethe field notes of the Korean teacher-researcher, the first author of this paper, who designed and implemented the CaMP in Korea. She chronologically recorded her students’ behaviours and attitudes in her classroom in detail throughout her teaching and classroom observation. Even though there were no formal interviews with participants, informal conversations with students during the program were also recorded in her field note and offered authors insightful 
understandings about their learning experiences. The second major data source were Korean students' responses to the program evaluation questionnaire that included 6 open-ended questions about their English learning experiences in the program. We analyzed these two sets of written texts using the constant comparative methods (Strauss \& Corbin, 1990). Three dimensions of the coding schemes consisted of acting subjects (teacher, student, and group), five stages and seven learning tasks of the program (See Table 1 in the next section) and the three literacies. Third, students' learning outcomes including media products, the class website transcripts (e.g., students’ profiles, discussion entries, text-based chat records) were also collected and analyzed focusing on assessing the effectiveness of the program for students’ multiliteracies acquisition.

To ensure the "trustworthiness" of our qualitative research findings, we utilized the concept of "critical friends” (Lincoln \& Guba, 1985). That is, throughout the program, the first author had recursive discussion and reflective conversation about her teaching and observation with the second author, an Iranian teacher-researcher, who taught the partner class in Iran, as a meansto deepen their understanding. Also, the first author analyzed the collected data and then the second and the third author double checked the results and collaboratively revised them to increase its reliability.

Results

\section{Computer-assisted Multiliteracies Program Design and Website Development}

There were three design principles for the CaMP: 1) To provide EFL students with authentic opportunities to communicate with other EFL students in different countries in English using CMC technologies. Through this principle we hoped to increase students' English learning motivation as well as present an experiential view of English as an international communication tool. 2) To invite EFL students to bring their own cultural understandings, instead of teacher-transmitted knowledge about the U.S. or the Western culture, into classroom dialogues and to participate in intercultural communications. These dialogues were seen as a potential tool to transform students' perspectives about English from that 
Lee, K., Ardeshiri, M., \& Cummins, J. (2016). A computer-assisted multiliteracies programme as an alternative approach to EFL instruction. Technology, Pedagogy and Education. doi: 10.1080/1475939X.2015.1118403

of native-speakers' English to a broader conceptualization of world Englishes and to develop their critical awareness of cultural diversity in the global society. 3) To engage EFL students in collaborative media production that enables students to construct and deliver their own ideas in various digital forms as active knowledge producers. Together, these principles involve learning and teaching three types of literacy: English language literacy, cultural literacy, and media literacy.

The basic structure of the CaMP process was to connect two EFL classes in different cultural contexts, where each class spoke different non-English languages, in order to provide a series of intercultural communication opportunities using English. The CaMP had five learning stages and included seven multiliteracies tasks (See table 1). Each task concerns two or more kinds of literacies, for example, the “one-to-one communication” task, for which each Korean student was paired with one Iranian student, is relevant to a written form of English language literacy, cultural literacy, and web-based media literacy. The "Collaborative media project”, is associated with both oral and written forms of English language literacy, cultural literacy, and various digital forms of media literacy since students used a variety of digital technologies to present their cultural understanding.

Table 1. CaMP Structure

\begin{tabular}{|c|c|c|}
\hline Stages & Tasks & Task Description \\
\hline 1. Introduction & e-Profile writing & $\begin{array}{l}\text { [Individual writing assignment] } \\
\text { Writing an online profile about me }\end{array}$ \\
\hline 2. Individual reading & e-Text reading & $\begin{array}{l}\text { [Individual reading assignment] } \\
\text { Reading online documents about Iranian culture }\end{array}$ \\
\hline 3. Collective writing & $\begin{array}{l}\text { Collaborative media } \\
\text { project }\end{array}$ & $\begin{array}{l}\text { [Group project] } \\
\text { Producing videos about Korean culture }\end{array}$ \\
\hline \multirow[t]{3}{*}{$\begin{array}{l}\text { 4. Intercultural } \\
\text { communication }\end{array}$} & $\begin{array}{l}\text { Class-to-class } \\
\text { communication }\end{array}$ & $\begin{array}{l}\text { [Class conversation] } \\
\text { Discussing cultural differences and similarities between Korea } \\
\text { and Iran on a discussion board }\end{array}$ \\
\hline & $\begin{array}{l}\text { One-to-one } \\
\text { communication }\end{array}$ & $\begin{array}{l}\text { [1:1 conversation] } \\
\text { Discussing cultural differences and similarities between Korea } \\
\text { and Iran through a text-based chat }\end{array}$ \\
\hline & e-Conference & $\begin{array}{l}\text { [Class or } 1: 1 \text { conversation] } \\
\text { Discussing cultural differences and similarities between Korea } \\
\text { and Iran using web-conferencing tools }\end{array}$ \\
\hline 5. Reflection & e-Blogging & $\begin{array}{l}\text { [Individual writing assignment] } \\
\text { Writing about individual learning experiences in a personal } \\
\text { weblog }\end{array}$ \\
\hline
\end{tabular}



approach to EFL instruction. Technology, Pedagogy and Education. doi: 10.1080/1475939X.2015.1118403

Through the CaMP website, the EFL classes in Korea and Iran were connected to each other and sequentially participated in the series of shared learning stages. The important design principles embodied in this website are: 1) 'Simple Interface’, 2) ‘Standard Platform’ and 3) ‘Structured Scaffold’. The purpose of the design principle 'Simple Interface' is to support all EFL teachers who are not familiar with teaching in CMC environments. Rather than including vast numbers of tools, we selected and embedded the most essential features (e.g., discussion board, chat tool, messaging tool) required for conducting interclass communicative tasks. Figure 1 is the main screen seen when the Korean teacher logs-in to the site. She simply signed-up for the website to create her own class website and then registered all her students to give them access to the class website. The main menus ${ }^{1)}$ on the upper red banner indicate the sequential learning stages, so that teachers and students would not be confused with where to go in each learning stage. Having Korean class profile ${ }^{2)}$ on the left and Iranian partner class' profile ${ }^{3)}$ on the right, students could have a sense of presence of two classes connected to each other and the time difference between the two countries is also displayed. When Iranian students log-in, the locations of two class profiles are switched. The class profiles are easily entered by individual teachers although to connect their class to the partner class, website administrators' approval was obtained. Even though basic tools ${ }^{4)}$ such as notes, scheduler, bulletin board, and the class calendar are embedded, students were encouraged to use other available CMC tools outside the class website such as Facebook and Skype ${ }^{5)}$ if required. Therefore, the interface is simple and straightforward for users to navigate. 

approach to EFL instruction. Technology, Pedagogy and Education. doi: 10.1080/1475939X.2015.1118403

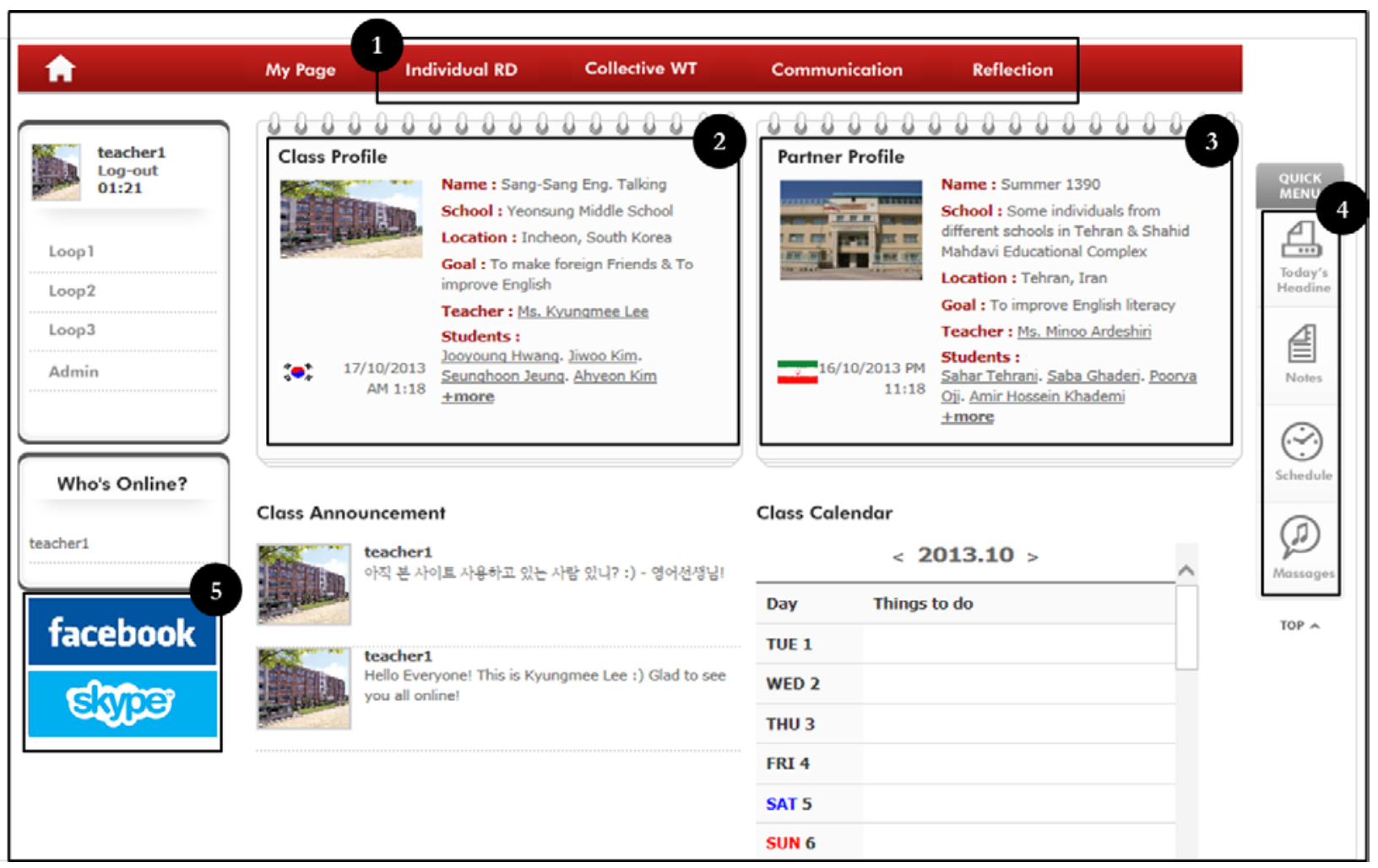

Figure 1. An Interface of the CaMP Website

Since different classrooms have their own internet and computer specifications, this website was developed based on international web standards. This 'Standard Platform' operates with different web browsers including Windows Internet Explorer and Safari so that all students and teachers could access the site regardless of their web environments. It includes a number of structured scaffolds for both students' learning tasks and teachers' class management practices. For example, EFL teachers can use structured forms (e.g., fill-in-the-blanks) under the admin view to form student groups, set up the discussion board for each group, and write instruction and announcements for different tasks.

\section{Learning experiences in the CaMP}

In the first stage 'Introduction,' students worked on an individual assignment involving writing an online profile about themselves in English. The teacher introduced the class website and how to use different CMC tools for their communicative tasks and helped her students join the class website and write their 
Lee, K., Ardeshiri, M., \& Cummins, J. (2016). A computer-assisted multiliteracies programme as an alternative approach to EFL instruction. Technology, Pedagogy and Education. doi: 10.1080/1475939X.2015.1118403

profiles in the computer-lab. This profile writing was a structured task so when students filled in the all blanks with their photo, name, nickname, grade, contact information, interest and short greeting message to other students, their profiles appeared in a structured format as shown in Figure 2. From the beginning of the program, all students showed great excitement at the novel instructional approach and several Korean students also signed up for 'Facebook' or other social network sites and shared the account information on their online profile.
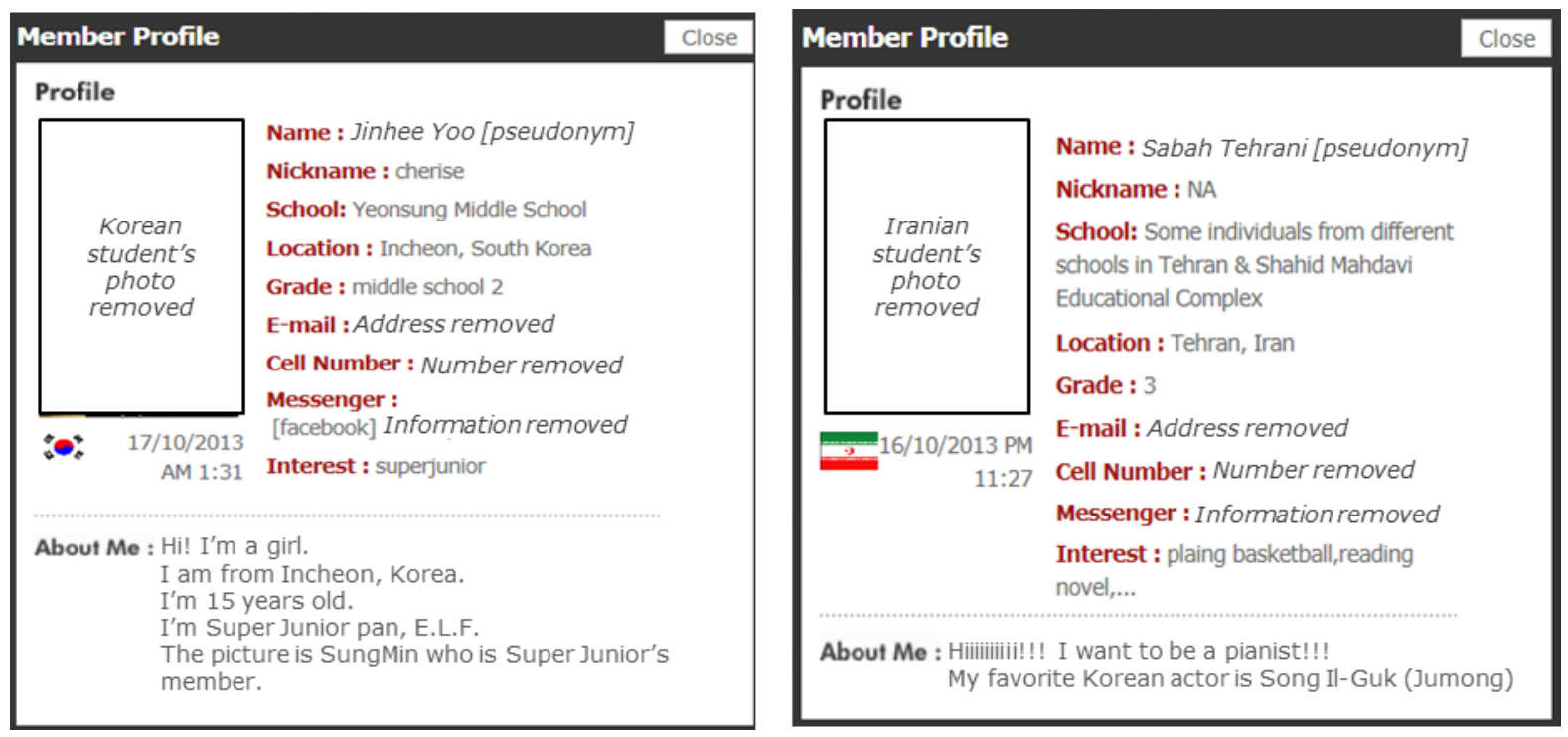

Figure 2. Students' e-Profiles

In the second stage 'Individual reading,' each student searched and read hypertext documents on the Internet (e.g., Wikipedia) and visited and explored different web pages about Iran through clicking hyperlinks. Although the teacher initially suggested different examples of search topics and keywords (e.g., capital, climate, and history) to facilitate students' online research experiences and suggested they read the documents written in English, students did not limit their exploration to those specific topics or language. Korean students found a great number of pages and media resources written in English, Korean and Persian languages and the themes of their research ranged from popular Iranian television shows and celebrities, to women's fashion. The topics that students chose to read about reflected the contemporary 

approach to EFL instruction. Technology, Pedagogy and Education. doi: 10.1080/1475939X.2015.1118403

youth culture and popular culture, that is, their current interests and concerns. Students did not only bring information about Iran but also many questions to the class such as "Can Iranian girls wear jeans or a miniskirt in public? Do they have to wear 'hijab' when go to school? Isn't it uncomfortable?” and “do Iranian middle school students abstain from food during Ramadan?”

In the third stage 'Collective writing', groups of Korean students participated in a collaborative media projectin which they developed media products tointroduce Korean culture to their Iranian 'friends' (Korean students started to refer to Iranian students as friends around this time although they yet had not had any direct contact with them). The entire process of the group project was conducted by students with minimum linguistic and technical supports from the teacher (e.g., correcting grammar in students' scripts, uploading videos on YouTube site). Students collaboratively explored and discussed about the meaning of culture and diverse cultural, social, and political issues in Korea to explain Korean culture in more effective ways to their Iranian friends. Through this collaborative learning process, it was observed, students broadened and deepened their understanding of 'culture' beyond what was explained and represented in their textbooks. Students also expanded their understanding of 'writing' from individual and text-based practice to collaborative and multimodal practice. As a result, all five groups produced video clips regarding different aspects of Korean culture such as: “A short greeting from Korea. Talking about Korea and us!”, “Do you know about Korea? Delicious foods and hottest stars”, “Do you know Hanbok? Korean traditional clothes”, “Welcome to Seoul”, and “Dokdo vs. Takeshima. Whose territory is this small island?” (Figure 3).

One of the groups produced a political massage "Dokdo belongs to Korea”: they decided to introduce the political issues related to Dokdo, a small island between Korea and Japan, resulting in long-lasting argument about sovereignty over the land. Five students in this group first read a large volume of online articles and postings written in English, developed a presentation slide and script, videotaped their presentation, and inserted English captions (e.g., title and ending credits) into the video. 

approach to EFL instruction. Technology, Pedagogy and Education. doi: 10.1080/1475939X.2015.1118403

Considering that it was both their first time developing a video product and that individual students' level of English was not as high as the complexity of the topic they chose, it can be argued that this collaborative media project improved students’ media literacy along with English language literacy. All videos were uploaded on YouTube and the links to them were shared through the class website. Korean students also watched video clips that their Iranian friends developed to introduce Iran.

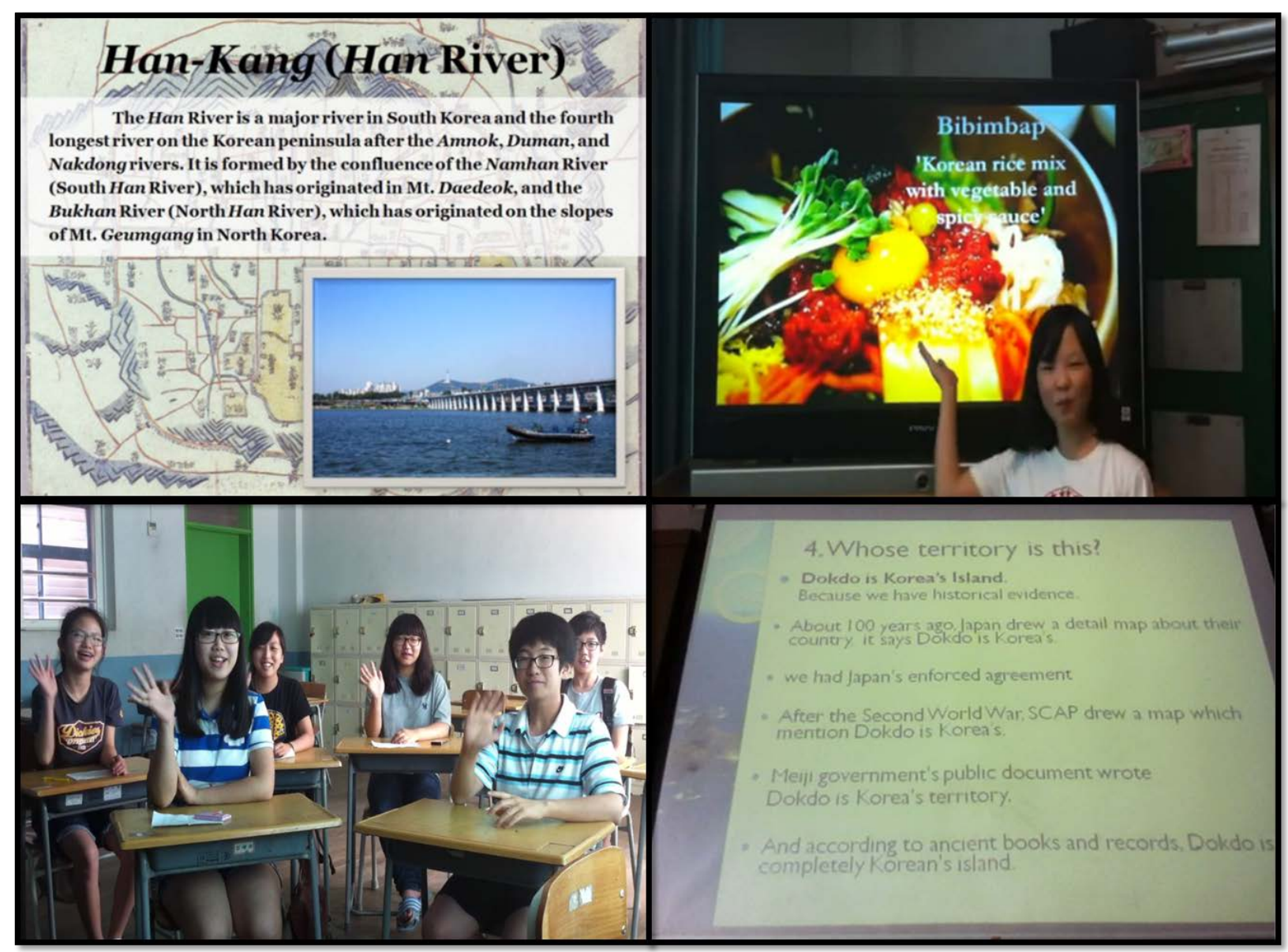

Figure 3. Student’ Media Products

This fourth stage of 'Intercultural communication' included three different levels of communication. The first task was ‘class-to-class communication' on an online discussion board, which all students from both classes could access. The students introduced themselves more in detail and built a mutual relationship with each other through this open discussion. The second communicative task was 
Lee, K., Ardeshiri, M., \& Cummins, J. (2016). A computer-assisted multiliteracies programme as an alternative approach to EFL instruction. Technology, Pedagogy and Education. doi: 10.1080/1475939X.2015.1118403

‘one-to-one communication' in which students had an online text-based chat with their Iranian conversation partner. Students could have authentic English speaking opportunities with their partners in their private chat room and some students mentioned that this private written-communication was helpful for them to overcome their fear of using English in public. The teacher monitored the conversations between students and provided different linguistic and emotional supports to students who were not able to initiate or continue the conversation due to their limited level of English language competence. In order to build a stronger presence of the partner class and engage students in actual communication practice, the teacher also invited the Iranian teacher to her classroom via a conferencing tool so that students were able to ask different questions emerging from their previous reading and communication activities. The Korean teacher translated what the Iranian teacher said when required. Through this 'e-Conference' process Korean students were able to increase their cultural understanding of Iran. After the conference, a few students said that the Iranian teacher’s English accent (as well as Iranian friends’ accent on video clips) was somewhat different from Americans and difficult to understand and some students also mentioned that the Korean English accent is also strange. The class discussed World Englishes and concluded that there was no single standard English in this global world.

In the class website, each student had his or her own personal blog. Students were asked to reflect on their learning practices and English communication or media production experiences. To engage students in deeper reflection, the teacher allowed them to write their journal entries in both Korean and English, as researchers (Cummins, 2001; García-Sánchez \& Rojas-Lizana, 2012) have suggested the effectiveness of bilingual writing practices for the second language learning. Also, students were able to use these personal spaces for the other purposes such as practicing their writing, brainstorming ideas, or collecting resources.

In their responses to the program evaluation questionnaire, students expressed satisfaction at having a chance to meet and talk to Iranian friends through the program $(\mathrm{N}=17)$ and a sense of 
achievement in the collaborative media project $(\mathrm{N}=15)$. To the question asking about their personal goal in relation to learning English, 12 students mentioned that they would spend more time and effort to improve their English communicative competenceso to make more foreign friends. 6 students responded that they would like to learn more about diverse cultures in different parts of the world and travel around the world including Iran and mentioned that improving their English seems one of the most important requirements to achieve their goal. The transformation of students' perspectives on English language learning was evident in students’ responses below:

Before this summer, I did not like English class, which was really boring, but honestly this summer English program was lots of fun. I could learn English naturally by having conversation with Iranian friends and producing a video in English with my classmates.

I liked making foreign friends. I wish I could have spoken English well enough to have much deeper conversation with them. I will study English harder to get close to them.

I was fun. I was glad that I could study English freely without taking a test. I want to continue taking this kind of English classes.

At the same time, however, students reported several limitations of their learning experiences in the CaMP, which include that: 1) their relatively low level of English communicative competence limited their conversation to rather a superficial level, 2) there was a lack of time for them to develop a close friendship with their partners in the three week-long course, and 3) in relation to the second point, the heavy workload of the program may be too burdensome during regular school semesters.

\section{The Promise for EFL Instruction}

The purpose of this paper is to introduce the idea of a computer-assisted multiliteracies program (CaMP) as an alternative pedagogical approach to EFL education. In EFL learning settings, there is an increasing gap between a strong emphasis on the acquisition of English communication skills and a lack 

approach to EFL instruction. Technology, Pedagogy and Education. doi: 10.1080/1475939X.2015.1118403

of authentic English communication opportunities. Although emerging information and communication technologies have been implemented in EFL classrooms to address their contextual limitations, EFL students have continued to face multiple difficulties with improving their English communication competence as well as subsequent social issues related to English education. A lack of authentic English learning opportunities, in particular, has led to excessive financial investment by families in private education, which has increased unequal levels of English among students from different socio-economic classes. Such limited access to international and intercultural communication opportunities has also limited EFL students' perception of English as being only standard American or native speakers’ English. To address these issues in EFL education, the CaMP aims to provide students with intercultural English communication opportunities through connecting two EFL classes in different countries and to allow students to increase their understanding of diverse cultures in the world. Through a series of intercultural communication tasks with other EFL students in their partner class, EFL students are naturally exposed to diverse cultural and linguistic approaches to English, that is, world Englishes. A collaborative video production about their culture enables students to be active meaning makers, which may improve their cultural awareness, and, at the same time, expand their understanding of communication to include multimodal practices.

The initial implementation of the CaMP suggests that effective application of different CMC tools based on the well-developed instructional model enhances EFL students’ learning motivation and overcomes a number of critical limitations in EFL educational settings. Future studies, however, will need to implement the CaMP or similar pedagogical efforts and more carefully examine their long-term effects on EFL students' acquisition of multiliteracies. Having considered the challenging nature of assessing students’ multiliteracies (Botelho et al, 2014; Jacobs, 2013), developing effective assessment tools for both students' learning processes and outcomes in similar multiliteracies programs will be required to measure the effectiveness of the program further. 
Lee, K., Ardeshiri, M., \& Cummins, J. (2016). A computer-assisted multiliteracies programme as an alternative approach to EFL instruction. Technology, Pedagogy and Education. doi: 10.1080/1475939X.2015.1118403 
Lee, K., Ardeshiri, M., \& Cummins, J. (2016). A computer-assisted multiliteracies programme as an alternative approach to EFL instruction. Technology, Pedagogy and Education. doi: 10.1080/1475939X.2015.1118403

\section{References}

Alexander, B. (2008). Web 2.0 and Emergent Multiliteracies. Theory into Practice, 47, 150-160. doi:10.1080/00405840801992371

Aronowit, S., \& Giroux, H. (1991). Textual Authority, culture, and the politics of literacy. In M. Apple \& L. K. Christian-Smith, (eds.), The politics of the textbook (pp. 213 - 241). New York, NY: Routledge.

Barman, S., \& Miluwi, J. O. (2013). Linguistic Imperialism and interpretation of intercultural approaches to English language teaching in a changing world. International Journal of Research in Social Sciences, 3(1), 435-447.

Bax, S. (2003). The end of CLT: A context approach to language teaching. ELT Journal, 57(3), 278-287.

Bonk, C. J. (2009). The world is open: How web technology is revolutionizing education. San Francisco, CA: Jossey-Bass.

Botelho, M. J., Kerekes, J., Jang, E. E., \& Peterson, S.S. (2014). Assessing Multiliteracies: Mismatches and Opportunities. Language and Literacy, 16(1). 1-20.

Bowen, W. (1996). Defining media literacy: Summary of the Harvard Institute on media education. Asheville, NC: Citizens for Media Literacy.

Bray, E. (2010). Using videomail (Vmail) effectively in online intercultural exchanges. CALL-EJ Online, 11(2). Retrieved from http://callej.org/journal/11-2/bray.html

Brown, H. D. (2006). Principles of Language Learning and Teaching ( $5^{\text {th }}$ ed.). White Plains, NY: Longman.

Buckingham, D. (2003). Media education and the end of the critical consumer. Harvard Educational Review, 73(3), 309-327.

Buckingham, D. (2007). Media education goes digital: an introduction. Learning, Media and Technology, 32(2), 111-119.

Butler, Y. G. (2005). Comparative perspectives towards communicative activities among elementary 
Lee, K., Ardeshiri, M., \& Cummins, J. (2016). A computer-assisted multiliteracies programme as an alternative approach to EFL instruction. Technology, Pedagogy and Education. doi: 10.1080/1475939X.2015.1118403

school teachers in South Korea, Japan and Taiwan. Language Teaching Research, 9(4), 423-446.

Butler, Y. G. (2011). The implementation of communicative and task-based language teaching in the Asia-Pacific region. Annual Review of Applied Linguistics, 31(1), 36-57.

Byram, M. (1997). Teaching and assessing intercultural communicative competence. Clevedon, UK: Multilingual Matters.

Byram, M. (2012). Language awareness and (critical) cultural awareness- relationships, comparisons and contrasts. Language Awareness, 21(1-2), 5-13.

Collins, A., Joseph, D., \& Bielaczyc, K. (2004). Design Research: Theoretical and methodological issues. Journal of the Learning Sciences, 13(1), 15-42. doi: 10.1207/s15327809jls1301_2

Coluzzi, P. (2012). Modernity and globalisation: Is the presence of English and of cultural products in English a sign of linguistic and cultural imperialism? Results of a study conducted in Brunei Darussalam and Malaysia. Journal of Multilingual and Multicultural Development, 33(2), 117-131. doi:10.1080/01434632.2011.640401

Cooper, N., Lockyer, L., \& Brown. I. (2013). Developing multiliteracies in a technology-mediated environment. Educational Media International, 50(2), 93-107. doi: $10.1080 / 09523987.2013 .795350$

Cope, B., \& Kalantzis, M. (2009). Multiliteracies: New literacies, new learning. Pedagogies: An International Journal, 4, 164-195. doi:10.1080/15544800903076044

Cummins, J. (2001). Negotiating identities: Education for empowerment in a diverse society (2nd ed.). Los Angeles, CA: California Association for Bilingual Education.

Cummins, J., \& Sayers, D. (1995). Brave new schools. New York, NY: St. Martin's Press.

Cummins, J., Brown, K., \& Sayers, D. (2007). Literacy, technology, and diversity: Teaching for success in changing times. Boston, MA: Allyn \& Bacon.

Edelson, D. C. (2002). Design research: What we learn when we engaged in design. Journal of the Learning Sciences, 11(1), 105-121. doi:10.1207/S15327809JLS1101_4 
Lee, K., Ardeshiri, M., \& Cummins, J. (2016). A computer-assisted multiliteracies programme as an alternative approach to EFL instruction. Technology, Pedagogy and Education. doi: 10.1080/1475939X.2015.1118403

Erstad, O. (2006). A new direction? : Digital literacy, student participation and curriculum reform in Norway. Education and Information Technologies, 11(3-4). 415-429.

Feigenbaum, H. (2011). America's Cultural Challenge Abroad. Political Science Quarterly, 126(1), 107-129.

García-Sánchez, S., \& Rojas-Lizana, S. (2012). Bridging the language and cultural gaps: the use of blogs. Technology, Pedagogy and Education, 21(3). 361-381. doi:10.1080/1475939X.2012.719396

Gee, J. P. (2012). The old and the new in the new digital literacies. The Educational Forum, 76(4). 418-420.

Giroux, H. (Ed.). (1999). Disney and the politics of public culture. In The mouse that roared: Disney and the end of innocence (pp. 17 - 61). New York, NY: Rowman \& Littlefield Publishers, Inc.

Golonka, E. M., Bowles, A. R., Frank, V. M., Richardson, D. R., \& Freynik, S. (2012): Technologies for foreign language learning: a review of technology types and their effectiveness. Computer Assisted Language Learning, 27(1), 70-105. DOI: 10.1080/09588221.2012.700315

Gramsci, A. (1971). Selections from the Prison Notebooks. London, UK: Lawrence and Wishart.

Guo, Y. (2012). Teaching English for Economic Competiveness: Emerging Issues and Challenges in English Education in China. Canadian and International Education, 41(2), 28-50.

Guth, S., \& Helm, F. (2012). Developing multiliteracies in ELT through telecollaboration. ELT Journal, 66(1), 42-51. doi: 10.1093/elt/ccr027

Hirsch, E. D. (1988). Cultural literacy: What every American needs to know: New York, NY: Vintage Books.

Hsu, H. Y., Wang, S. K., \& Comac, L. (2008). Using audioblogs to assist English-language learning: an investigation into student perception. Computer Assisted Language Learning, 21(2), 181-198.

Jacobs. G. E. (2013). Designing Assessments: A Multiliteracies Approach. Journal of Adolescent \& Adult Literacy, 56(8), 623-626. 
Lee, K., Ardeshiri, M., \& Cummins, J. (2016). A computer-assisted multiliteracies programme as an alternative approach to EFL instruction. Technology, Pedagogy and Education. doi: 10.1080/1475939X.2015.1118403

Jameson, F., \& Masao, M. (Eds.). (1998). The cultures of globalization. Durham, NC: Duke University Press.

Jenkins, H. (2004). The cultural logic of media convergence. International Journal of Cultural Studies, 7 , 33-43. doi:10.1177/1367877904040603

Jenkins, H. (2006). Why Heather can write: media literacy and the Harry Potter Wars. In Convergence culture: where old and new media collide. (pp. 175 - 216). New York, NY: NYU Press.

Jeon, J. (2009). Key issues in applying the communicative approach in Korea: Follow up after 12 years of implementation. English Teaching, 64(1), 123-150.

Jiang, Z. (2011). A Research and Counter-measures of English Cultural Hegemony in China. Asian Social Science, 7(1), 194-200.

Jin, D. Y. (2007). Reinterpretation of cultural imperialism: Emerging domestic market vs continuing US dominance. Media, Culture \& Society, 29(5), 753-771.

Kalantzis, M., \& Cope, B. (2008). Language education and multiliteracies. In S. May \& N. H. Hornberger (Eds.), Encyclopedia of Language and Education (2nd ed.), Volume 1: Language Policy and Political Issues in Education (pp. 195-211). New York, NY: Springer.

Kennedy, A. (2006). Globalisation, global English: ‘futures trading’ in early childhood education. Early Years, 26(3), 295-306.

Kim, Y. (2006). English fever in Korea: Impacts on the teaching of English and social issues that arise. The Internet Journal of Language, Society and Culture, 16. Retrieved July 25, 2014 from http://www.educ.utas.edu.au/users/tle/JOURNAL/ARTICLES/2006/16-1.htm.

Kim, J. (2010). 'Downed’ and stuck in Singapore: Lower/middle class South Korean wild geese (kiroki) children in Singapore. In E. Hannum, H. Park, Y. G. Butler (Eds.), Globalization, changing demographics, and educational challenges in East Asia. (pp. 271 - 311). Bingley, UK: Emerald Group Publishing Limited. 

approach to EFL instruction. Technology, Pedagogy and Education. doi: 10.1080/1475939X.2015.1118403

Kim, T. (2013). 영어학습 동기 연구의 최근 경향 [Recent trends in English learning motivation research]. Seoul, South Korea: Hankook Munhwasa.

Koltay, T. (2011). The media and the literacies: media literacy, information literacy, digital literacy. Media, Culture \& Society, 33(2), 211-221.

Kramsch, C. (1998). Language and Culture. Oxford, UK: Oxford University Press.

Kramsch, C. (2014). Teaching foreign languages in an era of globalization: Introduction. The Modern Language Journal, 98(1), 296-311.

Lee, B. (2010). The pre-university English-educational background of college freshmen in a foreign language program: a tale of diverse private education and English proficiency. Asia Pacific Education Review, 11(1), 69-82.

Li, D. (1998). "It's always more difficult than you plan and imagine”: Teachers' perceived difficulties in introducing the communicative approach in South Korea, TESOL Quarterly, 32(4), 677-703.

Lin, A. (1999). Doing-English-Lessons in the reproduction or transformation of social worlds? TESOL Quarterly, 33(3), 393-412.

Lincoln, Y. S., \& Guba, E. G. (1985). Naturalistic inquiry. Beverly Hills, CA: Sage.

Liu, L., \& Zhang, Y. (2014). The application of constructivism to the teaching of intercultural communication. English Language Teaching, 7(5), 136-141. doi:10.5539/elt.v7n5p136

Lussier, D. (2007). Theoretical bases of a conceptual framework with reference to intercultural communicative competence. Journal of Applied Linguistics, 4(3), 309-332. doi:10.1558/japl.v4i3.309

Mahdi, T. S., \& El-Naime, M. E. M. (2012). Effects of informal use of computer-mediated communication on EFL learner interaction. Studies in Literature and Language, 5(3), 75-81. doi:10.3968/j.sll.1923156320120503.801

Metiri Group. (2003). enGauge 21st century skills: Literacy in the digital age. Naperville, IL: North Central Regional Educational Laboratory, Metiri Group. 
Lee, K., Ardeshiri, M., \& Cummins, J. (2016). A computer-assisted multiliteracies programme as an alternative approach to EFL instruction. Technology, Pedagogy and Education. doi: 10.1080/1475939X.2015.1118403

Mills, K. A. (2009). Multiliteracies: interrogating competing discourses. Language and Education, 23(2), 103-116.

Moats, L. (2000). Speech to print: Language essentials for teachers. Baltimore, MD: Paul H. Brookes Pub.

Moran, P. (2001). Teaching culture: Perspectives in practices. Boston, MA: Heinle Cengage Learning.

New London Group (1996). A pedagogy of Multiliteracies: Designing social futures. Harvard Educational Review 66(1), 60-92.

Nowell, S. D. (2014). Using disruptive technologies to make digital connections: Stories of media use and digital literacy in secondary classrooms. Educational Media International, 51(2), 109-123.

Nunan, D. (2003). The impact of English as a global language on educational policies and practices in the Asia-Pacific region. TESOL Quarterly, 37(4), 589-613.

O'Dowd, R. (2007). Evaluating the outcomes of online intercultural exchange. ELT Journal, 61(2), $144-152$

OECD (2011). Education at glance 2011: OECD indicators. OECD Publishing. Retrieved from http://dx.doi.org/10.1787/eag-2011-en

Park, S. J., \& Abelman, N. (2004). Class and cosmopolitan striving: Mothers' management of English education in South Korea. Anthropological Quarterly, 77(4), 645-672.

Park, J. K. (2009). ““English fever” in South Korea: Its history and symptoms.’ English Today, 25(1), 507.

Qu, W. (2011). English, Identity and Critical Literacy. Changing English, 18(3), 297-307.

Schenker, T. (2012). Intercultural competence and cultural learning through telecollaboration. CALICO Journal, 29(3), 449-470.

Sefton-Green, J., Nixon, H., \& Erstad, O. (2009). Reviewing approaches and perspectives on “Digital Literacy” Pedagogies: An International Journal, 4(2), 107-125. 

approach to EFL instruction. Technology, Pedagogy and Education. doi: 10.1080/1475939X.2015.1118403

Sercu. L. (2002). Autonomous learning and the acquisition of intercultural communicative competence: Some implications for course development. Language, Culture and Curriculum, 15(1), 61-74. doi:10.1080/07908310208666633

Shim R. J., \& Baik, M. J. (2000). Korea (South and North). In W. K. Ho \& R. Y. L. Wong (Eds.), Language policies and language education: The impact in East Asian countries in the next decade (pp. 173 - 196). Singapore: Times Academic.

Shin, H. (2010). “Gireogi Gajok”: Transnationalism and language learning. Unpublished PhD dissertation. OISE, University of Toronto, Canada.

Song, J. J. (2011). English as an official language in South Korea Global English or social malady? Language Problems \& Language Planning, 35(1), 35-55.

Strauss, A., \& Corbin, J. (1990). Basics of qualitative research: Grounded theory procedures and techniques. Newbury Park, CA: Sage Publications.

Stockwell, G. (2007). A review of technology choice for teaching language skills and areas in the CALL literature. ReCALL, 19, 105-120.

Tan, L., \& Guo, L. (2014). Multiliteracies in an Outcome-Driven Curriculum: Where Is Its Fit? The Asia-Pacific Education Researcher, 23(1), 29-36. doi: 10.1007/s40299-013-0082-0

Tanghe, S. (2014). Integrating World Englishes into a university conversation class in South Korea. English Today, 30(2), 18-23. doi:10.1017/S026607841400008X

UNESCO (2004). The Plurality of Literacy and its implications for Policies and Programs. UNESCO Education Sector Position Paper, 13, 1-32.

Warschauer, M. (2000). The changing global economy and the future of English teaching. Tesol Quarterly, 34(3), 511-535.

Weaver, J. A. (2009). Popular Culture Primer (Rev. ed.). New York, NY: Peter Lang Publishing. Wigham, C. (2013). Review of contemporary computer-assisted language learning. Language Learning \& Technology, 17(2), 26-31. 
Lee, K., Ardeshiri, M., \& Cummins, J. (2016). A computer-assisted multiliteracies programme as an alternative approach to EFL instruction. Technology, Pedagogy and Education. doi: 10.1080/1475939X.2015.1118403

Yang, Y. F. (2011). Engaging students in an online situated language learning environment. Computer Assisted Language Learning, 24(2), 181-198. doi:10.1080/09588221.2010.538700

Yang, S. C., \& Chen, J. J. (2014). Forstering foreign language learning through technology-enhanced interultural projects. Language Learning \& Technology, 18(1), 57-75.

Yoo, O. K. (2005). Discourses of English as an official language in a monolingual society: The case of South Korea. Second Language Studies, 23(2), 1- 44.

Young, T. J., \& Sachdev, I. (2011). Intercultural communicative competence: exploring English language teachers' beliefs and practices. Language Awareness, 20(2). 81-98. doi:10.1080/09658416.2010.540328

Yunlong, H. (2014). Constructing intercultural communicative competence framework for English learners. Cross-Cultural Communication, 10(1), 97-101. doi:10.3968/j.ccc.1923670020141001.3970 